\title{
Acute Kidney Injury Epidemiology in pediatrics
}

\author{
Epidemiologia da lesão renal aguda em pediatria
}

\section{Authors}

Thais Lira Cleto-Yamane ${ }^{1}$ iD

Conrado Lysandro Rodrigues Gomes ${ }^{1}$

Jose Hermogenes Rocco

Suassuna ${ }^{1}$

Paulo Koch Nogueira ${ }^{2}$

${ }^{1}$ Universidade do Estado do Rio de Janeiro, Rio de Janeiro, RJ, Brasil.

2 Universidade Federal de São Paulo, São Paulo, SP, Brasil.

Submitted on: 06/13/2018 Approved on: 09/05/2018.

\section{Correspondence to:}

Thais Lira Cleto-Yamane.

E-mail: thaiscleto@yahoo.com.br

DOI: 10.1590 / 2175-8239-JBN-2018-0127

\section{Abstract}

We performed a search in the MEDLINE database using the MeSH term: "Acute Kidney Injury", selecting the subtopic "Epidemiology", and applying age and year of publication filters. We also searched for the terms: "acute renal failure" and "epidemiology" "acute tubular necrosis" and "epidemiology" in the title and summary fields with the same filters. In a second search, we searched in the LILACS database, with the terms: "acute renal injury", or "acute renal failure" or "acute kidney injury" and the age filter. All abstracts were evaluated by the authors and the articles considered most relevant, were examined in their entirety. Acute Kidney Injury (AKI) -related mortality ranged from $3-63 \%$ in the studies included in this review. AKI etiology has marked regional differences, with sepsis being the main cause in developed countries. In developing countries, primary renal diseases and hypovolemia are still a common cause of AKI.

Keywords: Renal Failure; Acute Kidney Injury; Epidemiology.

\section{Resumo}

Foi realizada busca na base de dados MEDLINE utilizando o termo MeSH "Acute Kidney Injury”, selecionando o subtópico "Epidemiology", e aplicados os filtros de idade e ano de publicação. Também foram realizadas buscas pelos termos "acute renal failure" e "epidemiology" "acute tubular necrosis" e "epidemiology" nos campos título e resumo com os mesmos filtros. $\mathrm{Na}$ segunda busca, foram pesquisadas palavras na base de dados LILACS, com os termos "lesão renal aguda", "insuficiência renal aguda" ou "injuria renal aguda" e o filtro de idade. Todos os resumos foram avaliados pelos autores e os artigos considerados mais relevantes, examinados na íntegra. A mortalidade relacionada à Lesão Renal Aguda (LRA) variou entre 3-63\% nos estudos incluídos nesta revisão. A etiologia da LRA tem marcantes diferenças regionais, sendo sepse a principal causa em países desenvolvidos. Em países em desenvolvimento, as doenças renais primárias e a hipovolemia ainda configuram causas frequentes de LRA.

Palavras-chave: Insuficiência Renal; Lesão Renal Aguda; Epidemiologia.

\section{INTRODUCTION}

Acute kidney injury (AKI) is defined as the sudden reduction in renal function that can range from discrete changes in biochemical markers to kidney failure requiring artificial renal support (ARS). It is a severe complication, with high morbidity and mortality in critically-ill patients, and it is often of multifactorial etiology. ${ }^{1}$

Until the early 2000s, the absence of standardization for diagnosis, with the existence of more than 30 published definitions for $\mathrm{AKI},{ }^{2}$ made it impossible to determine its magnitude, as well as the comparison between the different studies on the subject. The most widely available studies deal primarily with AKI requiring ARS, reporting mortality rates between $11 \%$ and $63 \%$ in pediatric patients. Children who presented with AKI had longer periods of hospitalization and stayed in a pediatric intensive care unit (PICU), and had a greater need for mechanical ventilation. ${ }^{5,6}$ In addition, children surviving an episode of AKI may progress with chronic kidney disease (up to $60 \%$ of children remain with proteinuria, hypertension, and some degree of reduced glomerular filtration rate (GFR)). ${ }^{7-9}$ 
The need for uniformity in the definition of AKI resulted in the creation of the first standardized definition published in 2004, called RIFLE (Risk, Injury, Failure, Loss, End-stage). Three years afterwards, these criteria were adapted to the pediatric population, giving rise to the pediatric RIFLE (pRIFLE) acronym. ${ }^{10}$ Since then, this criterion has undergone two other modifications, the most recent one being the KDIGO (Kidney Disease: Improving Global Outcome) rating system published in 2012.11

ARS is the most effective treatment for severe AKI in critically-ill patients. The first reports of hemodialysis (HD) use in humans date back to the 1940s, when Kolff et al. described the use of the socalled "artificial kidney" in a 29-year-old woman with chronic glomerulonephritis and uremia. ${ }^{12}$ In 1957, the same author described the advances in the equipment developed until then and mentioned the indications for using the artificial kidney, including AKI secondary to shock. The use of HD in children required more time to be implemented due to persistent difficulties, such as the small vessel size in pediatric patients and the need for large volumes to fill the extracorporeal circuit. ${ }^{14}$ In 1957, the first report of HD cases in children was published, describing clinical improvement and greater ease in conservative management after its use in 5 five children from 2 to 14 years of age. ${ }^{14}$ However, this modality has not proved safe for infants and young children. In this context, Segar et al. described the importance of using peritoneal dialysis in patients under 1 year of age and/ or under $15 \mathrm{~kg}$.

From the earliest reports of AKI to the present day, there has been significant improvement in the techniques and availability of dialysis procedures, as well as dramatic changes in epidemiology, especially regarding the causes of AKI. Primary renal diseases predominated, such as acute glomerulonephritis and hemolytic-uremic syndrome. After the advent of intensive care, sepsis, large surgeries (such as cardiac surgeries) and oncological problems became the most frequent causes, ${ }^{16,17}$ although in developing countries, dehydration is still a relevant cause of AKI. ${ }^{18-20}$ In addition, there have also been technological advances to care for younger children. In 2015, the first hemodialysis in a neonate with AKI was described using a new equipment, specifically developed for this age group.

The aim of this paper is to review the history and to describe the main information about the epidemiology of AKI in pediatric patients.

\section{Methods}

For this review, we searched the MEDLINE database through the PUBMED portal, using the Mesh term (Medical Subject Headings) "Acute Kidney Injury", selecting the subtopic "Epidemiology". We then applied filters for age (0 to 18 years) and year of publication (last 5 years) were then applied. This search, carried out in April 2017, resulted in 306 papers. We also searched the terms "acute renal failure" and "epidemiology", "acute tubular necrosis" and "epidemiology", in the "title" and "abstract" fields with the same filters (age and year of publication), selecting eight and no paper at all, respectively. The authors evaluated all abstracts, and the papers considered most relevant were examined in their entirety. A second search was carried out in the LILACS database (Latin American and Caribbean Literature in Health Sciences) through the Virtual Health Library portal, using a series of papers on the epidemiology of AKI in Brazil and Latin America, using the following search terms: "acute kidney injury" or "acute renal failure" or "acute renal injury" and the age filter (0 to 18 years). This second search selected 302 papers, which had their summaries examined by the authors. The most relevant papers were evaluated in their entirety; and the selected ones were included in this review. In addition, we carried out direct searches to obtain historical papers on the subject. Papers cited by selected authors and considered relevant were also included in this review.

\section{AKI CLASSIFICATION}

The first standard definition for AKI was the RIFLE classification, published in 2004. It is an acronym with the initials of the five proposed phases for the AKI classification: risk, injury, failure, loss of function, and end-stage renal disease. This classification was based on two widely available markers for renal function: changes in serum creatinine or glomerular filtration rate and urine output. ${ }^{2}$ However, the values considered in its creation contemplated changes in GFR and serum creatinine in adult patients, making it impossible to apply it to the pediatric age group. Within this context, an adaptation of this classification was published in 2007 for the pediatric age group. The P-RIFLE used the estimated reduction in creatinine clearance $(\mathrm{CrCl})$ to measure changes in renal function. ${ }^{10}$ 
Advances in the studies on the consequences of AKI in critically-ill patients showed that even small increases in serum creatinine caused higher mortality, which led to the development of the Acute Kidney Injury Network (AKIN) for AKI. This new model classified AKI in three stages, according to its severity, with stage 1 defined as an increase of $0.3 \mathrm{mg} / \mathrm{dL}$ in serum creatinine in relation to the baseline value. ${ }^{22}$

In 2012, the KDIGO classification was established, aiming to unify the three existing classifications to simplify and universalize its use, since it can be used for adult and pediatric patients. This definition, the most current one available in the literature, also takes into account two easily verified characteristics: serum creatinine (or estimated $\mathrm{CrCl}$ for patients under 18 years of age) and urine output. ${ }^{11}$ Although it is the most current and adequate classification for the pediatric age group, there was still a need for adaptation to the neonatal period, a phase in which renal physiology has particularities. Thus, the KDIGO classification for AKI in the neonatal period was published in $2015,{ }^{23}$ in which stage $2 \mathrm{AKI}$ is when there is reduced urine output for a shorter period; and the absolute value of serum creatinine is greater than or equal to $2.5 \mathrm{mg} /$ $\mathrm{dL}$ is considered stage 3 , since it represents a $\mathrm{CrCl}$ lower than $10 \mathrm{~mL} / \mathrm{min} / 1.73 \mathrm{~m}^{2}$ in neonates. Another peculiarity is that the baseline creatinine value is defined as the lowest previous value, since creatinine at birth reflects maternal creatinine, and physiologically evolves with falls during the first days of life. ${ }^{23}$

The estimated $\mathrm{CrCl}$ calculation is done using the Schwartz formula, which considers that $\mathrm{CrCl}$ is the result of the multiplication of the patient's height in centimeters by a constant $k$, divided by serum creatinine in $\mathrm{mg} / \mathrm{dL} .{ }^{24,25}$ The original formula uses serum creatinine as measured by the Jaffe method and the k-constant varying according to the patient's age range. ${ }^{24}$ The most current version of the Schwartz formula uses a single value for the constant $\mathrm{k}=$ 0.413 , regardless of age group and serum creatinine as measured by the enzymatic method. ${ }^{25}$

Estimated creatinine clearance $\left(\mathrm{mL} / \mathrm{min} / 1.73 \mathrm{~m}^{2}\right)$ $=\mathrm{k} X$ height $(\mathrm{cm}) /$ serum creatinine $(\mathrm{mg} / \mathrm{dL})$

Table 1 illustrates the described classifications for AKI.

\section{Global Epidemiology of Pediatric AKI}

Epidemiological data demonstrating the significant financial cost and high morbidity and mortality associated with $\mathrm{AKI}^{26}$ have been reported in studies on this subject involving pediatric patients in the literature, in recent years. However, these studies are still concentrated in developed countries. Data on AKI characteristics in developing countries remain scarce.

The first large epidemiological study involving a large number of pediatric patients was published in 2010, using the p-RIFLE for AKI diagnosis. An incidence of AKI of $11 \%$ has been demonstrated in patients between 31 days and 21 years of age admitted to a PICU in a single US center. A subsequent multicenter study in the same country described the incidence of 3.9 cases $/ 1,000$ hospitalizations and there was a need for ARS in $8.8 \%$ of the cases. The authors also reported higher mortality in the group requiring ARS (27.1\% versus $14.2 \% p<0.001) .{ }^{27}$ In a prospective assessment involving 226 children aged 0-14 years submitted to RRT at a single center in New Zealand in the period 2001-2006, the authors reported a mortality rate of $11 \% .{ }^{16}$

New studies have been published using the KDIGO classification as a criterion for the diagnosis of AKI. In a retrospective cohort of 8,260 ICU patients, of whom 974 were diagnosed as having AKI according to the KDIGO criteria, $25.3 \%$ mortality was observed in 28 days, being higher in patients who did not recover during the observation period $(40.5 \%$ $\mathrm{x} 11.2 \%, \mathrm{p}<0.01) .{ }^{28}$ More recently, in a prospective analysis of 4,984 patients between 3 months and 25 years of age, admitted to 32 PICUs in 4 continents, an incidence of $26.9 \%$ of AKI at any stage and mortality of $11 \%$ in patients with AKI stages 2 or 3 versus $3.4 \%$ in patients who did not develop AKI have been reported. ${ }^{29}$ In another large epidemiological study carried out in the United States, published in 2014, the authors assessed preterm extreme low-weight and an incidence of AKI of $39.8 \%$ was reported, according to the modified KDIGO classification for the neonatal period, as well as a higher mortality and hospitalization time adjusted for the severity of the patient. ${ }^{30}$

Available studies on the epidemiology of pediatric AKI in developing countries are mostly observational studies carried out in a single center. An exception is a study involving 388,736 patients under the age of 18 years admitted to 27 Chinese hospitals, which reported an incidence of AKI (AKIN) of $0.32 \%$ and a mortality rate of $3.4 \%$ in patients who developed AKI at any stage. ${ }^{18}$ Studies in Nigeria, India, Thailand and Pakistan showed mortality rates of $41.5 \%, 50.4 \%$ and $30 \%$, respectively. ${ }^{19,20,31,32}$ 


\section{TABLE 1 AKI AVAILABLE CLASSIFICATIONS}

\begin{tabular}{|c|c|c|c|c|}
\hline Classification & Year & Stage & Creatinine & Urinary output \\
\hline \multirow{5}{*}{ RIFLE $^{2}$} & \multirow{5}{*}{2004} & $\mathrm{R}$ & Increase $\geq 1.5 x$ or GFR reduction $\geq 25 \%$ & \multirow{5}{*}{$\begin{array}{c}<0.5 \mathrm{~mL} / \mathrm{kg} / \mathrm{h} \text { per } 6 \mathrm{~h} \\
<0.5 \mathrm{~mL} / \mathrm{kg} / \mathrm{h} \text { per } 12 \mathrm{~h} \\
<0.3 \mathrm{~mL} / \mathrm{kg} / \mathrm{h} \text { per } 24 \mathrm{~h} \\
\quad \text { or anuria for } 12 \mathrm{~h}\end{array}$} \\
\hline & & I & Increase $\geq 2 x$ or GFR reduction $\geq 50 \%$ & \\
\hline & & $\mathrm{F}$ & Increase $\geq 3 \times$ or creatinine $\geq 4 \mathrm{mg} / \mathrm{dL}$ & \\
\hline & & $L$ & Persistent failure or $>4$ weeks & \\
\hline & & E & Persistent failure for $>3$ months & \\
\hline \multirow{7}{*}{ p-RIFLE ${ }^{10}$} & \multirow{7}{*}{2007} & & Reduction in the estimated $\mathrm{CrCl} \geq 25 \%$ & \multirow{7}{*}{$\begin{aligned}< & 0.5 \mathrm{~mL} / \mathrm{kg} / \mathrm{h} \text { for } 8 \mathrm{~h} \\
< & 0.5 \mathrm{~mL} / \mathrm{kg} / \mathrm{h} \text { for } 16 \mathrm{~h} \\
< & 0.3 \mathrm{~mL} / \mathrm{kg} / \mathrm{h} \text { for } 24 \mathrm{~h} \\
& \text { or anuria for } 12 \mathrm{~h}\end{aligned}$} \\
\hline & & $\mathrm{R}$ & Reduction in the estimated $\mathrm{CrCl} \geq 50 \%$ & \\
\hline & & I & Reduction in the estimated $\mathrm{CrCl} \geq 50 \%$ & \\
\hline & & $\mathrm{F}$ & Reduction in the estimated $\mathrm{CrCl} \geq 75 \%$ or estimated $\mathrm{CrCl}<$ & \\
\hline & & $\mathrm{L}$ & $35 \mathrm{~mL} / \mathrm{min} / 1.73 \mathrm{~m}^{2}$ & \\
\hline & & $E$ & Persistent failure for $>4$ weeks & \\
\hline & & & Persistent failure for $>3$ months & \\
\hline \multirow{3}{*}{$\mathrm{AKIN}^{22}$} & \multirow{3}{*}{2007} & 1 & Increase $\geq 0,3 \mathrm{mg} / \mathrm{dL}$ or increase to $150-200 \%$ of baseline & $<0.5 \mathrm{~mL} / \mathrm{kg} / \mathrm{h}$ for $6 \mathrm{~h}$ \\
\hline & & 2 & Increase to $200-300 \%$ of baseline & $<0.5 \mathrm{~mL} / \mathrm{kg} / \mathrm{h}$ for $12 \mathrm{~h}$ \\
\hline & & 3 & $\begin{array}{c}\text { Increase to } \geq 300 \% \text { of baseline or } \mathrm{Cr} \geq 4 \mathrm{mg} / \mathrm{dL} \text { with sharp } \\
\text { increase of } 0.5 \mathrm{mg} / \mathrm{dL}\end{array}$ & $\begin{array}{l}<0.3 \mathrm{~mL} / \mathrm{kg} / \mathrm{h} \text { for } 24 \mathrm{~h} \\
\quad \text { or anuria for } 12 \mathrm{~h}\end{array}$ \\
\hline \multirow{3}{*}{$\mathrm{KDIGO}^{11}$} & \multirow{3}{*}{2012} & 1 & Increase of 0.3 mg/dL (in 48 h) or 150-200\% (in 7 days) & $<0.5 \mathrm{~mL} / \mathrm{kg} / \mathrm{h}$ for $8 \mathrm{~h}$ \\
\hline & & 2 & Increase $\geq 200-300 \%$ & $<0.5 \mathrm{~mL} / \mathrm{kg} / \mathrm{h}$ for $16 \mathrm{~h}$ \\
\hline & & 3 & $\begin{array}{c}\text { Increase } \geq 300 \%, \mathrm{Cr} \geq 4 \mathrm{mg} / \mathrm{dL} \text { or dialysis or eGFR }< \\
35 \mathrm{~mL} / \mathrm{min} / 1.73 \mathrm{~m}^{2} \text { for }<18 \text { years }\end{array}$ & $\begin{array}{l}<0.3 \mathrm{~mL} / \mathrm{kg} / \mathrm{h} \text { for } 24 \mathrm{~h} \\
\quad \text { or anuria for } 12 \mathrm{~h}\end{array}$ \\
\hline \multirow{5}{*}{$\begin{array}{l}\text { KDIGO } \\
\text { neonatal23 }\end{array}$} & \multirow{5}{*}{2015} & 0 & No increase or increase $<0.3 \mathrm{mg} / \mathrm{dL}$ & \multirow{5}{*}{$\begin{array}{c}\geq 0.5 \mathrm{mg} / \mathrm{kg} / \mathrm{h} \\
<0.5 \mathrm{mg} / \mathrm{dL} \text { for } 6-12 \mathrm{~h} \\
<0.5 \mathrm{mg} / \mathrm{dL} \text { for } \geq 12 \mathrm{~h} \\
<0.3 \mathrm{mg} / \mathrm{dL} \text { for } \geq 24 \mathrm{~h} \\
\text { or anuria for } \geq 12 \mathrm{~h}\end{array}$} \\
\hline & & 1 & Increase $\geq 0.3 \mathrm{mg} / \mathrm{dL}$ in $48 \mathrm{~h}$ or increase $\geq 1.5-1.9 x$ & \\
\hline & & 2 & & \\
\hline & & 3 & Increase $\geq 2.0-2.9 x$ reference value & \\
\hline & & $\checkmark$ & Increase $\geq 3 x$ reference value or $\mathrm{Cr} \geq 2.5 \mathrm{mg} / \mathrm{dL}$ or dialysis & \\
\hline
\end{tabular}

Data on the worldwide epidemiology of AKI are outlined in Table 2.

\section{Epidemiology of pediatric AKI In BraZIL}

Studies on the epidemiology of AKI in pediatric patients in Brazil are rare. In a retrospective study published in 2008 , a global mortality rate of $53.3 \%$ was reported in children aged 0 to 12 years in dialysis because of AKI, who underwent peritoneal dialysis, and it was even higher $(73.9 \%)$ in the neonatal period. ${ }^{33}$ Another study, published in 2009, selected 110 children from 1 month to 15 years of age, using serum creatinine values above the normal reference for age and height as inclusion criterion, with a lower overall mortality $(33.6 \%)$, probably due to the fact that patients less than 1 month old were excluded, and also by the inclusion of patients who had not yet reached the most severe stage of AKI. ${ }^{34}$ Studies using pRIFLE for diagnosis and classification of AKI stage in admitted patients in pediatric intensive care units showed that patients who developed AKI during hospitalization had a higher mortality rate and length of hospital stay than patients who maintained normal kidney function. ${ }^{35,36}$ In a more recent study, limited to sepsis-related AKI, a mortality rate of $33.7 \%$ was evidenced. The main risk factors for mortality were duration of hospitalization, use of mechanical ventilation, hypoalbuminemia and the need for dialysis. ${ }^{37}$ In a prospective epidemiological study in which pRIFLE and KDIGO criteria were used for the diagnosis of AKI, a similar prevalence of AKI was found with both $(49.4$ and $46.2 \%$, respectively). ${ }^{36}$ The observed mortality was $11.4 \%$ in patients with AKI diagnosed by pRIFLE and $12.2 \%$ in patients diagnosed with AKI according to KDIGO criteria. ${ }^{38}$ Table 3 summarizes the available epidemiological data available about pediatric AKI in Brazil. 


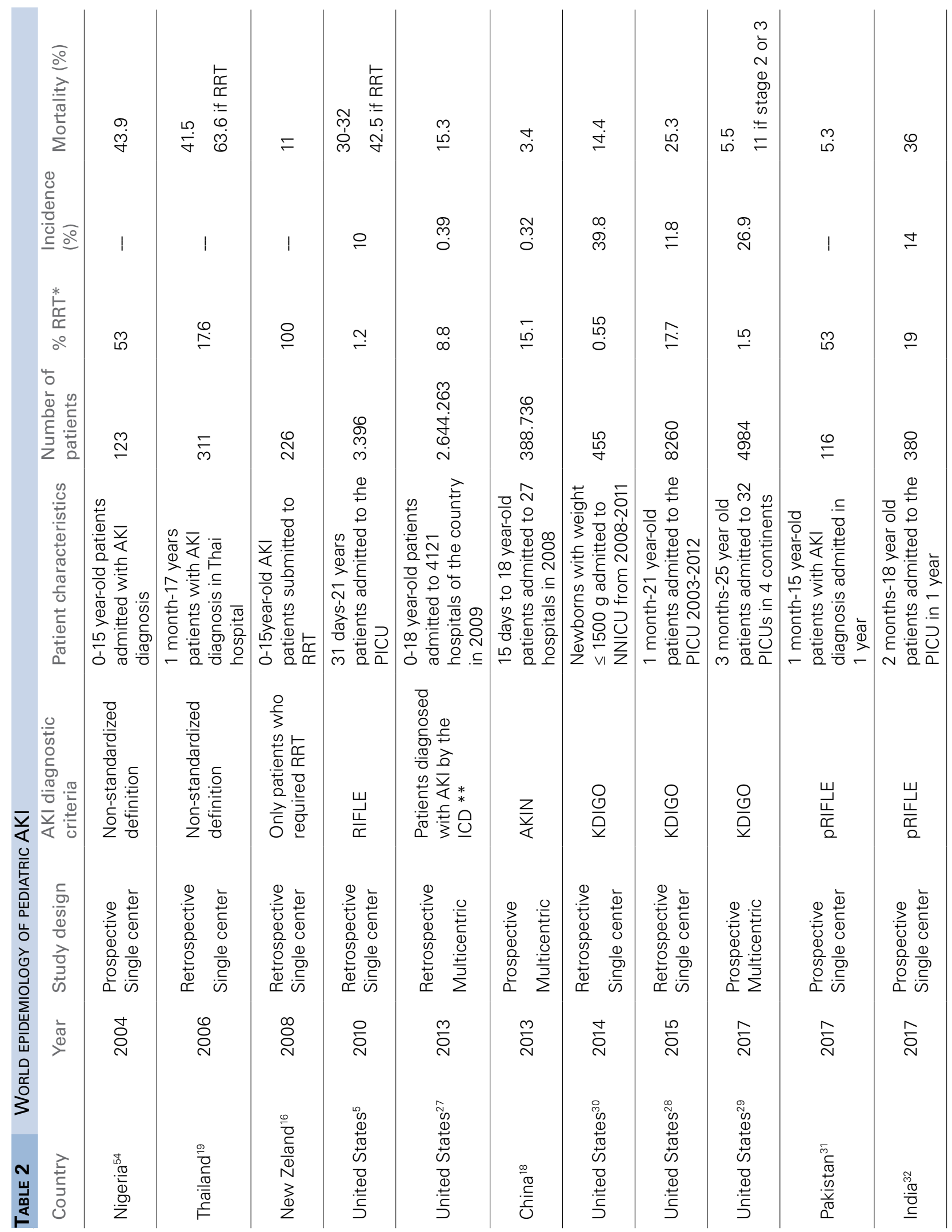


TABle 3 AKI EPIDEMIOLogy IN BRAZIL

\begin{tabular}{|c|c|c|c|c|c|c|c|}
\hline Year & Study design & $\begin{array}{c}\text { AKI diagnostic } \\
\text { criterion }\end{array}$ & $\begin{array}{c}\text { Patient } \\
\text { characteristics }\end{array}$ & $\begin{array}{c}\text { Number } \\
\text { of } \\
\text { patients }\end{array}$ & $\%$ RRT & Incidence & Mortality \\
\hline $2008^{33}$ & $\begin{array}{l}\text { Retrospective } \\
\text { Single center }\end{array}$ & $\begin{array}{l}\text { Patients } \\
\text { submitted to } \\
\text { peritoneal dialysis }\end{array}$ & $\begin{array}{l}0-12 \text { year-old patients } \\
\text { admitted to the } \\
\text { PICU or NNICU who } \\
\text { required PD between } \\
2002 \text { and } 2006\end{array}$ & 45 & 100 & - & 53.3 \\
\hline $2009^{34}$ & $\begin{array}{l}\text { Prospective } \\
\text { Single center }\end{array}$ & $\begin{array}{l}\text { Creatinine } \\
\text { higher than the } \\
\text { reference value } \\
\text { for age/height }\end{array}$ & $\begin{array}{l}0-15 \text { year-old patients } \\
\text { with AKI admitted to } \\
\text { the PICU between } \\
2002-2004\end{array}$ & 110 & 49.1 & 8 & 33.6 \\
\hline $2013^{35}$ & $\begin{array}{l}\text { Prospective } \\
\text { Single center }\end{array}$ & pRIFLE & $\begin{array}{l}28 \text { days-15 year-old } \\
\text { patients admitted to } \\
\text { the PICU during } 3 \\
\text { months }\end{array}$ & 126 & 12 & 46 & 36.2 \\
\hline $2015^{36}$ & $\begin{array}{l}\text { Retrospective } \\
\text { Single center }\end{array}$ & pRIFLE & $\begin{array}{l}29 \text { days- } 18 \text { year-old } \\
\text { patients admitted to } \\
\text { the PICU in } 1 \text { year }\end{array}$ & 375 & - & 54,9 & 16 \\
\hline $2016^{38}$ & $\begin{array}{l}\text { Prospective } \\
\text { Single center }\end{array}$ & pRIFLE/KDIGO & $\begin{array}{l}0-20 \text { years admitted } \\
\text { to the PICU in } 6 \\
\text { months }\end{array}$ & 160 & - & $\begin{array}{l}51,3 \% \\
\text { (pRIFLE) } \\
42 \% \\
\text { (KDIGO) }\end{array}$ & $\begin{array}{l}11,4 \% \\
\text { (pRIFLE) } \\
12,2 \% \\
\text { (KDIGO) }\end{array}$ \\
\hline $2017^{37}$ & $\begin{array}{l}\text { Retrospective } \\
\text { Single center }\end{array}$ & pRIFLE & $\begin{array}{l}1 \text { month-11-year old } \\
\text { patients admitted to } \\
\text { the PICU in } 4 \text { years } \\
\text { with a diagnosis of } \\
\text { sepsis and AKI }\end{array}$ & 77 & 42.8 & -- & 33.7 \\
\hline
\end{tabular}

\section{ETIOLOGY}

The first epidemiological studies on AKI, reported primary kidney disease as a common cause. ${ }^{39}$ With the advent of intensive therapy and technological advances that have improved care for critically ill patients, the etiologies of AKI have changed dramatically. Currently, multifactorial AKI is a reality because, in the intensive care setting, it is common for the same patient to remain exposed, for example, sepsis, shock and drug nephrotoxicity. In addition, complex cardiac surgeries and chemotherapeutic treatment for neoplasia also evolved and became more widely available, leaving these patients also exposed to the risk of AKI related to this health care.

These etiologic changes are most evident in developed countries, where more studies on AKI are available. In one study, involving patients admitted between 1999 and 2001 to a tertiary center in the United States, ischemia was still reported as the leading cause of AKI $(21 \%)$, followed by nephrotoxicity $(16 \%)$ and sepsis $(11 \%)$. These cases occurred prior to the dissemination of the concepts published by the Surviving Sepsis Campaign, when the onset of early parenteral antibiotic therapy and volume expansion became recommended as an essential therapy for the reduction of related mortality. ${ }^{41}$ In developed countries, current data point to sepsis and cardiac surgeries as etiologic agents related to AKI in critically ill patients. ${ }^{27,42}$ When we extend the assessment to hospitalized patients in less complex sectors, the importance of nephrotoxicity as an etiological factor becomes more evident, because although very present in the intensive care setting, its role in the development of AKI is clearly assessed in the absence of other risk factors. Goldstein et al. described the development of AKI in one-third of the low-complexity admissions in patients receiving aminoglycosides for $\geq 3$ days or patients who received $\geq 3$ nephrotoxic drugs during hospitalization. In neonates, in addition to sepsis, nephrotoxicity and cardiac surgery, perinatal asphyxia also plays an important role as AKI etiology. ${ }^{44}$

In developing countries, primary kidney diseases are still important causes of AKI in the pediatric population. In a multicenter study in China, published in 2013, acute glomerulonephritis was the major cause of AKI in the study population, followed by severe dehydration. ${ }^{18}$ 
Table 4 highlights the main etiologies of AKI according to the location and year in which the study was carried out.

\section{FUTURE PERSPECTIVES}

Currently being developed are extensive research in the search for predictive factors of AKI, which goals are to find factors that can predict or detect risks for the occurrence of AKI, allowing the problem to be avoided or attenuated. The widely used renal function marker, creatinine, is restricted due to its late increase in the course of AKI, as well as its susceptibility to changes by non-renal factors, such as gender, age and muscle mass. ${ }^{45}$ The new biomarkers appeared as a large promise in this regard. Among them, the most widely studied is neutrophil gelatinase-associated lipocalin (NGAL), which showed good accuracy for the detection of AKI after post-operative insult in cardiac surgeries, sepsis and contrast use. ${ }^{46-49}$

In order to improve the pre-test probability of available biomarkers in 2010, the concept of "renal angina" was developed, which uses features that indicate risk for AKI and early clinical signs of renal damage for its calculation, creating a predictor score of AKI, and which could serve as a screening tool to determine which patients should have their biomarkers dosed..$^{50,51}$ For the calculation of the "Renal Angina Index" (RAI), the authors defined factors that make the child susceptible to AKI, and early clinical signs of AKI (injury). The presence of each characteristic assigns a score, and the score obtained in "risk" is multiplied by the score obtained in "injury", resulting in the "Renal Angina Index". A result greater than or equal to 8 showed prediction for AKI on the 3rd day of admission with an area under the curve of $0.74-0.81 .^{52}$ Figure 1 illustrates how the RAI is calculated.

In a recent prospective study, urinary NGAL was incorporated into the RAI and they found that the combined model was able to predict severe and persistent AKI (KDIGO 2 or 3), with an area under the curve of $0.97 .{ }^{53}$ Although promising, these observations need to be replicated in other locations.

\begin{tabular}{|c|c|c|c|}
\hline TABLE 4 & AKI ETIOLO & S ACCORDING TO THE PLACE AND YEA & IDY \\
\hline Year & Study place & Patient characteristics & Main AKI etiologies \\
\hline $2005^{40}$ & United States & 0-21 year-old patients diagnosed with AKI. & Ischemia, nephrotoxicity and sepsis \\
\hline $2006^{19}$ & Thailand & 0-17 year-old patients diagnosed with AKI & sepsis, hypovolemia and ADG \\
\hline $2007^{10}$ & United States & 0-21 year-old patients with AKI. & pneumonia, sepsis and shock \\
\hline $2007^{4}$ & United States & $\begin{array}{l}\text { 0-25 year-old patients who received } \\
\text { Continuous Renal Replacement }\end{array}$ & $\begin{array}{l}\text { sepsis, bone marrow transplant and heart } \\
\text { diseases }\end{array}$ \\
\hline $2008^{16}$ & New Zealand & $\begin{array}{l}0-15 \text { year-old patients who received Renal } \\
\text { Replacement Therapy }\end{array}$ & $\begin{array}{l}\text { Heart surgery, hemolytic-uremic syndrome } \\
\text { and sepsis }\end{array}$ \\
\hline $2010^{42}$ & Spain & $\begin{array}{l}\text { Patients with a mean age of } 52 \text { months who } \\
\text { received Continuous Renal Replacement } \\
\text { Therapy }\end{array}$ & $\begin{array}{l}\text { Heart diseases, sepsis, and renal failure } \\
\text { flaring. }\end{array}$ \\
\hline $2013^{27}$ & United States & $\begin{array}{l}0-18 \text { year-old patients admitted to } 4,121 \\
\text { hospitals }\end{array}$ & shock, sepsis and liver diseases \\
\hline $2013^{18}$ & China & $\begin{array}{l}0-17 \text { year-old patients admitted to } 27 \\
\text { hospitals }\end{array}$ & $\begin{array}{l}\text { Acute glomerulonephritis, severe } \\
\text { dehydration and nephrotic syndrome }\end{array}$ \\
\hline $2016^{32}$ & India & $\begin{array}{l}0-18 \text { year-old patients admitted to the PICU } \\
\text { in } 1 \text { hospital }\end{array}$ & Shock, sepsis and respiratory failure \\
\hline $2016^{31}$ & Pakistan & $0-15$ year-old patients admitted in 1 hospital & $\begin{array}{l}\text { Post-infectious glomerulonephritis, } \\
\text { urolithiasis and crescent GN }\end{array}$ \\
\hline
\end{tabular}


Figure 1. Renal Angina Index calculation. Note: The result may vary between 1 and 40 . Values $\geq 8$ establishes the presence of renal angina. Source: translated and adapted from Basu et al. ${ }^{50}$

Risk factors

Pediatric ICU admission

Transplantation

Ventilation and inotropy
Risk

\section{Score}

\section{1}

3

\section{$\mathbf{X}$}

Decrease in $\mathrm{CrCl}$ $<0$ $1,0-1,49 x$ $1,5-1,99 x$ $>2 x$

\section{Score}

$1,0-1,49 x$
$1,5-1,99 x$
$>2 x$

$$
5-9,99 \%
$$

\section{Conclusion}

The AKI is a serious condition, with a multifactorial etiology in many cases, and with variable mortality, reaching more than $60 \%$ in patients undergoing dialysis. From the epidemiological point of view, there is still a significant lack of robust studies on the incidence, prevalence and outcomes of AKI in the pediatric population, notably in developing countries, such as ours. Promising studies aimed at early diagnosis and intervention may prevent its occurrence or mitigate its effects.

\section{References}

1. Andreoli SP. Acute kidney injury in children. Pediatr Nephrol 2009;24:253-63.

2. Bellomo R, Ronco C, Kellum JA, Mehta RL, Palevsky P; Acute Dialysis Quality Initiative workgroup. Acute renal failure - definition, outcome measures, animal models, fluid therapy and information technology needs: the Second International Consensus Conference of the Acute Dialysis Quality Initiative (ADQI) Group. Crit Care 2004;8:R204-12.
3. Hayes LW, Oster RA, Tofil NM, Tolwani AJ. Outcomes of critically ill children requiring continuous renal replacement therapy. J Crit Care 2009;24:394-400.

4. Symons JM, Chua AN, Somers MJ, Baum MA, Bunchman TE, Benfield MR, et al. Demographic characteristics of pediatric continuous renal replacement therapy: a report of the prospective pediatric continuous renal replacement therapy registry. Clin J Am Soc Nephrol 2007;2:732-8.

5. Schneider J, Khemani R, Grushkin C, Bart R. Serum creatinine as stratified in the RIFLE score for acute kidney injury is associated with mortality and length of stay for children in the pediatric intensive care unit. Crit Care Med 2010;38:933-9.

6. Zappitelli M, Bernier PL, Saczkowski RS, Tchervenkov CI, Gottesman R, Dancea A, et al. A small post-operative rise in serum creatinine predicts acute kidney injury in children undergoing cardiac surgery. Kidney Int 2009;76:885-92.

7. Askenazi DJ, Feig DI, Graham NM, Hui-Stickle S, Goldstein SL. 3-5 year longitudinal follow-up of pediatric patients after acute renal failure. Kidney Int 2006;69:184-9.

8. Mammen C, Al Abbas A, Skippen P, Nadel H, Levine D, Collet $\mathrm{JP}$, et al. Long-term risk of CKD in children surviving episodes of acute kidney injury in the intensive care unit: a prospective cohort study. Am J Kidney Dis 2012;59:523-30.

9. Sinha R, Nandi M, Tullus K, Marks SD, Taraphder A. Ten-year follow-up of children after acute renal failure from a developing country. Nephrol Dial Transplant 2009;24:829-33. 
10. Akcan-Arikan A, Zappitelli M, Loftis LL, Washburn KK, Jefferson LS, Goldstein SL. Modified RIFLE criteria in critically ill children with acute kidney injury. Kidney Int 2007;71:1028-35.

11. John A. Kellum, Norbert Lameire, Peter Aspelin, Rashad S. Barsoum, Emmanuel A. Burdmann, Stuart L. Goldstein et al. Kidney Disease: Improving Global Outcomes (KDIGO) Acute Kidney Injury Work Group KDIGO Clinical Practice Guideline for Acute Kidney Injury. Kidney Int Suppl 2012;2:1-138.

12. Kolff WJ, Berk HT, Welle M, van der Ley AJ, van Dijk EC, van Noordwijk J. Artificial kidney: dialyser with great area. Acta Med Scandinav 1944;117:121-34.

13. Kolff WJ. The artificial kidney; past, present, and future. Circulation 1957;15:285-94.

14. Carter FH Jr, Aoyama S, Mercer RD, Kolff WJ. Hemodialysis in children; report of five cases. J Pediatr 1957;51:125-36.

15. Segar WE, Gibson RK, Rhamy R. Peritoneal dialysis in infants and small children. Pediatrics 1961;27:603-13.

16. Ball EF, Kara T. Epidemiology and outcome of acute kidney injury in New Zealand children. J Paediatr Child Health 2008;44:642-6.

17. Goldstein SL. Acute kidney injury in children: prevention, treatment and rehabilitation. Contrib Nephrol 2011;174:163-72.

18. Cao Y, Yi ZW, Zhang H, Dang XQ, Wu XC, Huang AW. Etiology and outcomes of acute kidney injury in Chinese children: a prospective multicentre investigation. BMC Urol 2013;13:41.

19. Vachvanichsanong P, Dissaneewate P, Lim A, McNeil E. Childhood acute renal failure: 22-year experience in a university hospital in southern Thailand. Pediatrics 2006;118:e786-91.

20. Olowu WA. Acute kidney injury in children in Nigeria. Clin Nephrol 2015;83:70-4.

21. Ronco C, Ricci Z, Goldstein SL. (R)evolution in the Management of Acute Kidney Injury in Newborns. Am J Kidney Dis 2015;66:206-11.

22. Mehta RL, Kellum JA, Shah SV, Molitoris BA, Ronco C, Warnock DG, et al.; Acute Kidney Injury Network. Acute Kidney Injury Network: report of an initiative to improve outcomes in acute kidney injury. Crit Care 2007;11:R31.

23. Jetton JG, Askenazi DJ. Update on acute kidney injury in the neonate. Curr Opin Pediatr 2012;24:191-6.

24. Schwartz GJ, Brion LP, Spitzer A. The use of plasma creatinine concentration for estimating glomerular filtration rate in infants, children, and adolescents. Pediatr Clin North Am 1987;34:571-90.

25. Schwartz GJ, Muñoz A, Schneider MF, Mak RH, Kaskel F, Warady BA, et al. New equations to estimate GFR in children with CKD. J Am Soc Nephrol 2009;20:629-37.

26. Lewington AJ, Cerdá J, Mehta RL. Raising awareness of acute kidney injury: a global perspective of a silent killer. Kidney Int 2013;84:457-67.

27. Sutherland SM, Ji J, Sheikhi FH, Widen E, Tian L, Alexander SR, et al. AKI in hospitalized children: epidemiology and clinical associations in a national cohort. Clin J Am Soc Nephrol 2013;8:1661-9.

28. Sanchez-Pinto LN, Goldstein SL, Schneider JB, Khemani RG. Association Between Progression and Improvement of Acute Kidney Injury and Mortality in Critically Ill Children. Pediatr Crit Care Med 2015;16:703-10.

29. Kaddourah A, Basu RK, Bagshaw SM, Goldstein SL; AWARE Investigators. Epidemiology of Acute Kidney Injury in Critically Ill Children and Young Adults. N Engl J Med 2017;376:11-20.

30. Carmody JB, Swanson JR, Rhone ET, Charlton JR. Recognition and reporting of AKI in very low birth weight infants. Clin J Am Soc Nephrol 2014;9:2036-43.

31. Tresa V, Yaseen A, Lanewala AA, Hashmi S, Khatri S, Ali I, et al. Etiology, clinical profile and short-term outcome of acute kidney injury in children at a tertiary care pediatric nephrology center in Pakistan. Ren Fail 2017;39:26-31.

32. Rustagi RS, Arora K, Das RR, Pooni PA, Singh D. Incidence, risk factors and outcome of acute kidney injury in critically ill children - a developing country perspective. Paediatr Int Child Health 2017;37:35-41.

33. Tavares MS. Análise de mortalidade em crianças com insuficiência renal aguda submetidas à diálise peritoneal. J Bras Nefrol 2008;30:180-4 .

34. Bresolin N, Silva C, Halllal A, Toporovski J, Fernandes V, Góes J, et al. Prognosis for children with acute kidney injury in the intensive care unit. Pediatr Nephrol 2009;24:537-44.
35. Bresolin N, Bianchini AP, Haas CA. Pediatric acute kidney injury assessed by pRIFLE as a prognostic factor in the intensive care unit. Pediatr Nephrol 2013;28:485-92.

36. Cabral FC, Ramos Garcia PC, Mattiello R, Dresser D, Fiori HH, Korb C, et al. Influence of Acute Kidney Injury Defined by the Pediatric Risk, Injury, Failure, Loss, End-Stage Renal Disease Score on the Clinical Course of PICU Patients. Pediatr Crit Care Med 2015;16:e275-82.

37. Riyuzo MC, Silveira LV, Macedo CS, Fioretto JR. Predictive factors of mortality in pediatric patients with acute renal injury associated with sepsis. J Pediatr (Rio J) 2017;93:28-34.

38. Volpon LC, Sugo EK, Consulin JC, Tavares TL, Aragon DC, Carlotti A. Epidemiology and Outcome of Acute Kidney Injury According to Pediatric Risk, Injury, Failure, Loss, End-Stage Renal Disease and Kidney Disease: Improving Global Outcomes Criteria in Critically Ill Children-A Prospective Study. Pediatric Crit Care Med 2016;17:e22938.

39. Williams DM, Sreedhar SS, Mickell JJ, Chan JC. Acute kidney failure: a pediatric experience over 20 years. Arch Pediatr Adolesc Med 2002;156:893-900.

40. Hui-Stickle S, Brewer ED, Goldstein SL. Pediatric ARF epidemiology at a tertiary care center from 1999 to 2001. Am J Kidney Dis 2005;45:96101.

41. Dellinger RP, Carlet JM, Masur H, Gerlach H, Calandra T, Cohen J, et al.; Surviving Sepsis Campaign Management Guidelines Committee. Surviving Sepsis Campaign guidelines for management of severe sepsis and septic shock. Crit Care Med 2004;32:858-73.

42. Santiago MJ, Lopez-Herce J, Urbano J, Solana MJ, del Castillo J, Ballestero Y, et al. Clinical course and mortality risk factors in critically ill children requiring continuous renal replacement therapy. Intensive Care Med 2010;36:843-9.

43. Goldstein SL, Kirkendall E, Nguyen H, Schaffzin JK, Bucuvalas J, Bracke $T$, et al. Electronic health record identification of nephrotoxin exposure and associated acute kidney injury. Pediatrics 2013;132:e756-67.

44. Selewski DT, Charlton JR, Jetton JG, Guillet R, Mhanna MJ, Askenazi DJ, et al. Neonatal Acute Kidney Injury. Pediatrics 2015;136:e463-73.

45. Ciccia E, Devarajan P. Pediatric acute kidney injury: prevalence, impact and management challenges. Int J Nephrol Renovasc Dis 2017;10:7784.

46. Zhou F, Luo Q, Wang L, Han L. Diagnostic value of neutrophil gelatinase-associated lipocalin for early diagnosis of cardiac surgery-associated acute kidney injury: a meta-analysis. Eur J Cardiothorac Surg 2016;49:746-55.

47. Haase M, Bellomo R, Devarajan P, Schlattmann P, Haase-Fielitz A; NGAL Meta-analysis Investigator Group. Accuracy of neutrophil gelatinase-associated lipocalin (NGAL) in diagnosis and prognosis in acute kidney injury: a systematic review and meta-analysis. Am J Kidney Dis 2009;54:1012-24.

48. Haase-Fielitz A, Haase M, Devarajan P. Neutrophil gelatinase-associated lipocalin as a biomarker of acute kidney injury: a critical evaluation of current status. Ann Clin Biochem 2014;51:335-51.

49. Hirsch R, Dent C, Pfriem H, Allen J, Beekman RH 3rd, Ma Q, et al. NGAL is an early predictive biomarker of contrast-induced nephropathy in children. Pediatr Nephrol 2007;22:2089-95.

50. Chawla LS, Goldstein SL, Kellum JA, Ronco C. Renal angina: concept and development of pretest probability assessment in acute kidney injury. Crit Care 2015;19:93.

51. Goldstein SL, Chawla LS. Renal angina. Clin J Am Soc Nephrol 2010;5:943-9.

52. Basu RK, Zappitelli M, Brunner L, Wang Y, Wong HR, Chawla LS, et al. Derivation and validation of the renal angina index to improve the prediction of acute kidney injury in critically ill children. Kidney Int 2014;85:659-67.

53. Menon S, Goldstein SL, Mottes T, Fei L, Kaddourah A, Terrell T, et al. Urinary biomarker incorporation into the renal angina index early in intensive care unit admission optimizes acute kidney injury prediction in critically ill children: a prospective cohort study. Nephrol Dial Transplant 2016;31:586-94.

54. Olowu WA, Adelusola KA. Pediatric acute renal failure in southwestern Nigeria. Kidney Int 2004;66:1541-8. 